\title{
Bell Pepper (Capsicum annum L.) Crop as Affected by Shade Level: Fruit Yield, Quality, and Postharvest Attributes, and Incidence of Phytophthora Blight (caused by Phytophthora capsici Leon.)
}

Juan Carlos Díaz-Pérez ${ }^{1,2}$

Department of Horticulture, University of Georgia, 2360 Rainwater Road, Tifton, GA 31793-5766

Additional index words. Capsicum annum, climate change, fruit sunscald, heat stress, light responses, Phytophthora capsici

Abstract. High temperatures can be detrimental to bell pepper, resulting in reduced fruit yield and increased incidences of fruit disorders such as sunscald and blossom-end rot. Shade nets are used to modify the crop microenvironment to improve plant growth and yield. The objectives were to evaluate effects of shade level on fruit yield, quality, and postharvest attributes and the incidence of Phytophthora blight (caused by Phytophthora capsici Leon.) in bell pepper (Capsicum annum L.). Experiments were conducted in Tifton, GA, in 2008 (with cv. Heritage) and 2009 and 2010 (with cvs. Camelot, Lafayette, Sirius, and Stiletto). Bell pepper plants were grown under shade levels of $0 \%$ (unshaded, as a control), $30 \%, 47 \%, 63 \%$, and $80 \%$. Shade level affected fruit yield, quality, postharvest attributes, and incidence of Phytophthora blight in plants. Total marketable (Fancy and US1) fruit yield increased with increasing shade level to a maximum at $35 \%$ shade and then decreased with further increments in shade level. Relative to unshaded plants, marketable yields were improved by $119 \%$ (2008) and $43 \%$ (2009 and 2010) at 35\% shade level. US2 and cull (sunscald) fruit number declined with increasing shade level. 'Camelot' produced among the greatest number and yield of marketable fruit; 'Sirius' had the heaviest fruit and greatest number of culls. Fruit nitrogen $(\mathrm{N})$, phosphorus $(\mathrm{P})$, and potassium $(\mathrm{K})$ concentrations increased and aluminum (Al), molybdenum (Mo), and nickel (Ni) decreased with increasing shade level. 'Lafayette' had the highest fruit concentration of $\mathbf{N}$, calcium (Ca), sulfur (S), manganese (Mn), and zinc ( $\mathrm{Zn})$. Fruit soluble solids and percent of fruit dry weight decreased with increasing shade level; fruit water loss rate and bacterial soft rot incidence were unaffected. Fruit skin $a^{*}$ and $b^{*}$ values decreased in yellow fruit cultivars ('Lafayette' and 'Sirius') with increased shade level. Incidences of Phytophthora blight in plants and fruit sunscald decreased with shade level. Beneficial effects of shading on bell pepper were associated with a reduction in irradiation, air temperature, and soil temperature under shaded conditions resulting in amelioration of heat stress in the plants. Optimal shade level for maximal fruit yield was that which maximized the cooling effect resulting from reduction of infrared (IR) radiation and minimized the decrease in net photosynthesis resulting from reduction in photosynthetically active radiation $(P A R)$.

Bell pepper (Capsicum annum L.) is an important crop in the southeast United States and is typically grown in an open field on

Received for publication 4 Dec. 2013. Accepted for publication 23 May 2014.

Financial support provided by the Georgia Agricultural Experiment Stations.

My sincere gratitude to John Silvoy, Jesús Bautista, and Nélida Bautista for their invaluable technical support. Thanks also to Jason Brock of the Plant Disease Clinic, University of Georgia, Tifton Campus, for identification of plant diseases. I appreciate the thorough review of the manuscript by Patrick Conner, Tim Coolong, and the anonymous reviewers. Mention of trade names in this publication does not imply endorsement by the University of Georgia of products named, nor criticism of similar ones not mentioned.

${ }^{1}$ Professor.

${ }^{2}$ To whom reprint requests should be addressed; e-mail jcdiaz@uga.edu. in Israel report that shading increases plant growth and yield (Rylski and Spigelman, 1986), reduces water requirements, and increases irrigation water use efficiency in bell pepper (Moller and Assouline, 2007). Shading has also been shown to extend the season in bell pepper grown in tunnels in Florida, allowing for fruit production during the summer (Hochmuth et al., 2013).

There are few studies on use of shade nets for vegetable production in the southern United States (Boyhan et al., 2008; Roberts and Anderson, 1994; Russo, 1993). Shade nets are commonly used to modify the crop microenvironment with the goal of improving crop production (Castellano et al., 2008). Few reports, however, have focused on determining the relationship between shade level with plant growth and yield. Effects of shade level on crop microenvironment, plant growth, leaf gas exchange, and leaf mineral nutrient content in bell pepper have been reported (Díaz-Pérez, 2013). The objectives of this study were to evaluate the effects of shade level on incidences of Phytophthora blight and Tomato spotted wilt, fruit mineral nutrient content, bell pepper fruit yield, quality, and postharvest attributes.

\section{Materials and Methods}

The study was carried out at the Horticulture Farm, Univ. of Georgia, Tifton, GA, during the spring-summer seasons of 2008, 2009, and 2010. The soil was a Tifton Sandy Loam (a fine loamy-siliceous, thermic Plinthic Kandiudults) with $\mathrm{pH}$ 6.5. Bell pepper plants were grown on plastic film mulch on raised beds $(6 \times 0.76 \mathrm{~m}$, formed on $1.8-\mathrm{m}$ centers $)$. Before laying mulch, the soil was fertilized with $\mathrm{N}, \mathrm{P}$, and $\mathrm{K}$ at 60,26 , and $50 \mathrm{~kg} \cdot \mathrm{ha}^{-1}$, respectively, using $10 \mathrm{~N}-10 \mathrm{P}-10 \mathrm{~K}$ granular fertilizer. At the same time plastic film mulch [silver on black, low-density polyethylene with a slick surface texture, $1.52 \mathrm{~m}$ wide and $25 \mu \mathrm{m}$ thick (RepelGro; ReflecTek Foils, Inc., Lake Zurich, IL)] was laid with a mulch-laying machine, drip irrigation tape [20.3-cm emitter spacing and a $8.3-\mathrm{mL} \cdot \mathrm{min}^{-1}$ emitter flow (Ro-Drip; Roberts Irrigation Products, Inc., San Marcos, CA)] was placed $5 \mathrm{~cm}$ deep in the center of the bed.

Bell pepper transplants were produced in a greenhouse using peat-based medium (Pro-Mix, Quakertown, PA) and polystyrene 200 -cell $(2.5 \times 2.5$-cm cell $)$ trays. Six-week-old bell pepper transplants were planted with a mechanical transplanter on 18 Apr. 2008, 15 Apr. 2009, and 23 Apr. 2010 in two rows per bed with a $30-\mathrm{cm}$ separation between plants and $36-\mathrm{cm}$ separation between rows. Approximately $250 \mathrm{~mL}$ of starter fertilizer solution $\left(555 \mathrm{mg} \cdot \mathrm{L}^{-1} \mathrm{~N} ; 821 \mathrm{mg} \cdot \mathrm{L}^{-1} \mathrm{P}\right.$; $0 \mathrm{mg} \cdot \mathrm{L}^{-1} \mathrm{~K}$ ) was applied directly to the base of each transplant. The length of the experimental plot was $3.3 \mathrm{~m}$. Starting 3 weeks after transplanting, plants were fertilized weekly through the drip system with $\mathrm{N}$ and $\mathrm{K}$ at 225 and $229 \mathrm{~kg} \cdot \mathrm{ha}^{-1}$, respectively. Fertilization 
rates after transplanting were $0.7 \mathrm{~kg} \cdot \mathrm{ha}^{-1} \cdot \mathrm{d}^{-1}$ for both $\mathrm{N}$ and $\mathrm{K}$ in Week $2 ; 1.0 \mathrm{~kg} \cdot \mathrm{ha}^{-1} \cdot \mathrm{d}^{-1}$ for both $\mathrm{N}$ and $\mathrm{K}$ in Week $3 ; 1.5 \mathrm{~kg} \cdot \mathrm{ha}^{-1} \cdot \mathrm{d}^{-1}$ for both $\mathrm{N}$ and $\mathrm{K}$ in Week $4 ; 2.0 \mathrm{~kg} \cdot \mathrm{ha}^{-1} \cdot \mathrm{d}^{-1}$ for both $\mathrm{N}$ and $\mathrm{K}$ in Week $5 ; 2.5$ and $3.5 \mathrm{~kg} \cdot \mathrm{ha}^{-1} \cdot \mathrm{d}^{-1}$ for $\mathrm{N}$ and $\mathrm{K}$, respectively, in Week 6; 3.0 and $3.5 \mathrm{~kg} \cdot \mathrm{ha}^{-1} \cdot \mathrm{d}^{-1}$ for $\mathrm{N}$ and $\mathrm{K}$, respectively, in Weeks 7 to $8 ; 2.5$ and $3.5 \mathrm{~kg} \cdot \mathrm{ha}^{-1} \cdot \mathrm{d}^{-1}$ for $\mathrm{N}$ and $\mathrm{K}$, respectively, in Weeks 9 to 10; and 2.0 and $2.5 \mathrm{~kg} \cdot \mathrm{ha}^{-1} \cdot \mathrm{d}^{-1}$ for $\mathrm{N}$ and $\mathrm{K}$, respectively, in Weeks 11 to 15 .

Plants were irrigated to $100 \%$ crop evapotranspiration (ETc). ETc was calculated by multiplying the reference evapotranspiration (ETo) by the crop factor, which is dependent on the crop stage of development. Water was applied when cumulative ETc was $1.2 \mathrm{~mm}$, which corresponded to every $\approx 2$ to $3 \mathrm{~d}$ in mature plants (mean ETo was 5 to $6 \mathrm{~mm} \cdot \mathrm{d}^{-1}$ ). Weather data (air temperature, ETo, and rainfall) were obtained from a nearby University of Georgia weather station (less than $300 \mathrm{~m}$ ).

The experimental design was a randomized complete block with four replications and five treatments (shade level) in 2008 and four replications and 20 treatments (five shade $\times$ four cultivar combinations) in 2009 and 2010 . Shading treatments were $0 \%, 30 \%$, $47 \%, 63 \%$, and $80 \%$ reduction of $P A R$ (according to the manufacturer). In 2008, the cultivar was Heritage (Harris Moran, Modesto, CA) and in 2009 and 2010 cultivars were Camelot (Seminis, Oxnard, CA), Lafayette (Siegers Seed Co., Holland, MI), Sirius (Siegers Seed Co., Holland, MI), and Stiletto (Rogers, Boise, ID). 'Camelot' (red fruit) and 'Lafayette' (yellow fruit) are susceptible to Tomato spotted wilt (TSW). 'Sirius' (yellow fruit) and 'Stiletto' (red fruit) are resistant to TSW.

Polypropylene black shade nets (Baycor Industrial Fabric, Pendergrass, GA) were supported with metallic cable and posts forming a pyramidal structure with the highest point at $\approx 2 \mathrm{~m}$ along the center of the bed. Shade nets were set $\approx 4$ weeks after transplanting ( 15 May 2008, 12 May 2009, and 21 May 2010).

Microenvironment. In 2008, air temperature was measured with a temperature sensor located inside a WatchDog data logger (Model 12001; Spectrum Technologies). PAR and air, leaf, and root zone temperature for 2009 and 2010 were reported previously (Díaz-Pérez, 2013).

Leaf gas exchange and photosystem II efficiency. Simultaneous measurements of leaf gas exchange were made with an IR gas analyzer (LI-COR 6400 IRGA with an integrated 6400-40 leaf chamber fluorometer; LI-COR, Inc., Lincoln, NE), as described by Díaz-Pérez (2013). Measurements were conducted on 11 and 20 Aug., 8 Sept., and 1 Oct. 2009 and 28 and 30 July and 12 Aug. 2010.

Plant insects and diseases in the field. Insect populations and diseases were low. The only pesticide used was neem oil (GOS, Neem 7-Way; Neem Tree Farms, Brandon, FL). Plants were monitored weekly for presence of Phytophthora blight (caused by Phytophthora capsici Leon.) and TSW-symptomatic plants were tagged. Etiology of plant and fruit diseases was confirmed at the Plant Disease
Clinic, Univ. of GA, Tifton campus. Presence of TSW virus in symptomatic plants was confirmed by enzyme-linked immunosorbent assay on pepper leaves using a commercially available kit (Agdia Inc., Elkhart, IN).

Fruit mineral nutrients. Fruit (five ripe fruit per plot) were dried at $70{ }^{\circ} \mathrm{C}$ for $2 \mathrm{~d}$, ground, and analyzed for mineral nutrient concentration at the Univ. of Georgia Agricultural \& Environmental Services Laboratories, Athens, GA.

Harvest. In 2008, bell pepper fruit were harvested at the mature green stage on 9, 13, and 23 June, and 1, 16, 28 July, and 8 Aug. In 2009 and 2010, bell pepper fruit were harvested at the ripe stage (turning or fully colored) and graded according to the U.S. Department of Agriculture standards (USDA, 2005) as marketable or cull. Fruit were

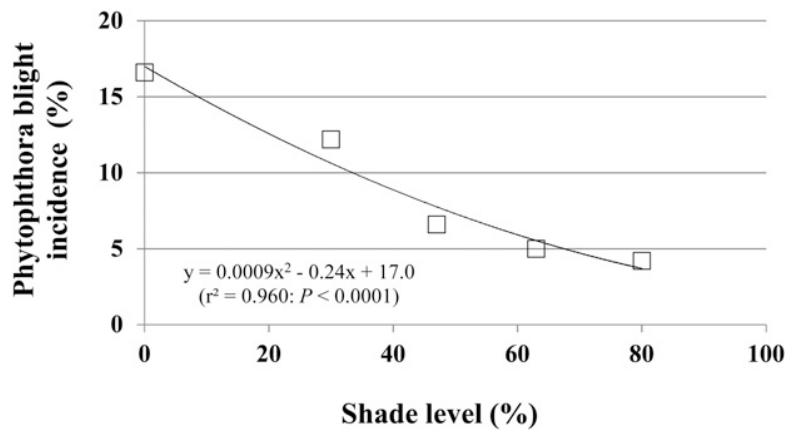

Fig. 1. Incidence of Phytophthora blight (caused by Phytophthora capsici) in bell pepper plants as a function of shade level. Incidence calculated as percentage of infected plants relative to total number of plants. Data for spring-summer of 2009 and 2010 from cultivars Camelot, Lafayette, Sirius, and Stiletto were pooled. Photosynthetically active radiation $(P A R)$ on clear days was $\approx 2100 \mu \mathrm{mol} \cdot \mathrm{m}^{-2} \cdot \mathrm{s}^{-1}$ in Tifton, GA.
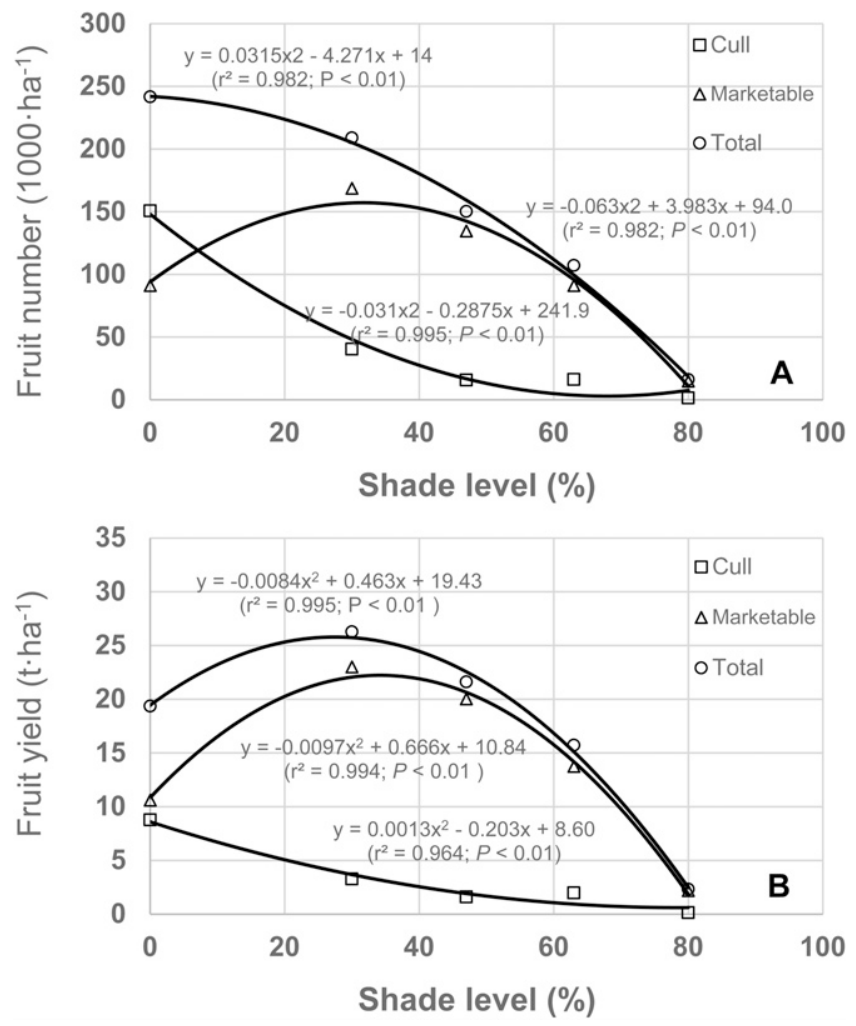

Fig. 2. Bell pepper ('Heritage') fruit number (A) and fruit yield (B) as a function of shade level under field conditions. Fruit were harvested at the mature-green stage. Photosynthetically active radiation $(P A R)$ on clear days was $\approx 2100 \mu \mathrm{mol} \cdot \mathrm{m}^{-2} \cdot \mathrm{s}^{-1}$ in Tifton, GA, spring-summer of 2008. 
values. Soluble solids concentration was measured with a refractometer (Atago 3810 PAL-1, Livermore, CA). Fruit dry weight was determined by drying fruit at $70{ }^{\circ} \mathrm{C}$. Percentage of fruit dry weight was calculated as:

$$
D W(\%)=[(D W / F W) * 100]
$$

where $D W$ is fruit dry weight and $F W=$ fruit fresh weight before drying.
Fruit water loss rate was measured by placing fruit on trays (10 fruit per plot) and kept in a controlled-temperature room at $20{ }^{\circ} \mathrm{C}$, vapor pressure difference of $1.50 \mathrm{kPa}$, and air velocity of less than $0.2 \mathrm{~m} \cdot \mathrm{s}^{-1}$. Fruit water loss was measured gravimetrically by weighing individual fruit daily for $7 \mathrm{~d}$. The rate of water loss $(W L R)$ was determined as a daily percent weight loss of the fruit with

Table 1. Bell pepper yields of ripe fruit as affected by cultivar, Tifton, GA, spring and summer of 2009 and $2010 .^{z, y}$

\begin{tabular}{|c|c|c|c|c|c|c|}
\hline \multirow[b]{2}{*}{ Cultivar } & \multicolumn{2}{|c|}{ Marketable } & \multicolumn{2}{|c|}{ Cull } & \multirow{2}{*}{$\begin{array}{c}\text { Total } \\
\text { Yield } \\
\left(\mathrm{t} \cdot \mathrm{ha}^{-1}\right)\end{array}$} & \multirow[b]{2}{*}{$\frac{\text { Fruit wt }}{\text { (g/fruit) }}$} \\
\hline & $\begin{array}{l}\text { Number } \\
(1000 / \text { ha })\end{array}$ & $\begin{array}{c}\text { Yield } \\
\left(\mathrm{t} \cdot \mathrm{ha}^{-1}\right)\end{array}$ & $\begin{array}{l}\text { Number } \\
(1000 / \text { ha })\end{array}$ & $\begin{array}{c}\text { Yield } \\
\left(\mathrm{t} \cdot \mathrm{ha}^{-1}\right)\end{array}$ & & \\
\hline \multicolumn{7}{|l|}{2009} \\
\hline Camelot & $164 \mathrm{~b}$ & $18.0 \mathrm{a}$ & $31 \mathrm{c}$ & $2.8 \mathrm{c}$ & 20.7 & $116 \mathrm{a}$ \\
\hline Lafayette & $137 \mathrm{c}$ & $13.4 \mathrm{~b}$ & $62 \mathrm{~b}$ & $5.7 \mathrm{~b}$ & 19.1 & $98 \mathrm{~b}$ \\
\hline Sirius & $108 \mathrm{~d}$ & $11.1 \mathrm{~b}$ & $91 \mathrm{a}$ & $8.1 \mathrm{a}$ & 19.1 & $107 \mathrm{~b}$ \\
\hline Stiletto & $203 \mathrm{a}$ & $17.9 \mathrm{a}$ & $39 c$ & $2.6 \mathrm{c}$ & 20.5 & $89 \mathrm{c}$ \\
\hline$P$ & $<0.0001$ & $<0.0001$ & $<0.0001$ & $<0.0001$ & 0.394 & $<0.0001$ \\
\hline \multicolumn{7}{|l|}{2010} \\
\hline Camelot & $154 \mathrm{a}$ & $22.5 \mathrm{a}$ & $212 \mathrm{c}$ & $13.0 \mathrm{c}$ & $35.5 \mathrm{~b}$ & $151 \mathrm{~b}$ \\
\hline Lafayette & $144 \mathrm{ab}$ & $19.8 \mathrm{a}$ & $261 \mathrm{bc}$ & $22.6 \mathrm{a}$ & $42.4 \mathrm{a}$ & $138 \mathrm{~b}$ \\
\hline Sirius & $62 \mathrm{~b}$ & $11.0 \mathrm{c}$ & $313 \mathrm{ab}$ & $19.0 \mathrm{~b}$ & $29.9 \mathrm{c}$ & $181 \mathrm{a}$ \\
\hline Stiletto & $127 \mathrm{c}$ & $14.7 \mathrm{~b}$ & $356 a$ & $17.2 \mathrm{~b}$ & $31.8 \mathrm{bc}$ & $113 \mathrm{c}$ \\
\hline$P$ & $<0.0001$ & $<0.0001$ & 0.002 & $<0.0001$ & $<0.0001$ & $<0.0001$ \\
\hline \multicolumn{7}{|l|}{ Significance } \\
\hline Year $(Y)$ & $<0.0001$ & 0.031 & $<0.0001$ & $<0.0001$ & $<0.0001$ & $<0.0001$ \\
\hline Shade (S) & $<0.0001$ & $<0.0001$ & $<0.0001$ & $<0.0001$ & $<0.0001$ & $<0.0001$ \\
\hline $\mathrm{Y} * \mathrm{~S}$ & 0.009 & $<0.0001$ & $<0.0001$ & $<0.0001$ & $<0.0001$ & 0.607 \\
\hline Cultivar (C) & $<0.0001$ & $<0.0001$ & 0.0002 & $<0.0001$ & $<0.0001$ & $<0.0001$ \\
\hline $\mathrm{Y}^{*} \mathrm{C}$ & 0.0001 & 0.0004 & 0.004 & 0.001 & $<0.0001$ & $<0.0001$ \\
\hline $\mathrm{S} * \mathrm{C}$ & 0.001 & 0.001 & 0.682 & 0.238 & 0.158 & 0.427 \\
\hline $\mathrm{Y}^{*} \mathrm{~S} * \mathrm{C}$ & 0.483 & 0.585 & 0.613 & 0.980 & 0.475 & 0.880 \\
\hline
\end{tabular}

${ }^{\mathrm{z}}$ Means within the same column and year followed by the same letter are not statistically different according to Fisher's protected least significant difference test $(P \leq 0.05)$.

${ }^{y}$ Shade levels were $0 \%, 30 \%, 47 \%, 63 \%$, and $80 \%$. Photosynthetically active radiation on clear days was $\approx 2100 \mu \mathrm{mol} \cdot \mathrm{m}^{-2} \cdot \mathrm{s}^{-1}$. respect to the fruit weight the day before each measurement. The $W L R$ was calculated as:

$$
W L R\left(\% \text { day }^{-1}\right)=\left(\Delta F W / F W_{o}\right)(100 / t)
$$

where $\Delta F W$ is change in fruit $F W(\mathrm{~g})$ and $t$ is time period (day) between two consecutive fruit $F W$ determinations; and $F W_{o}$ is fruit $F W$ at the beginning of the weighing period. Mean values of $W L R$ were calculated for individual fruit from measurements made over a 7-d period. After the 7-d keeping period at $20{ }^{\circ} \mathrm{C}$, fruit were evaluated for presence of bacterial soft rot (caused by Erwinia spp.), which was reported as percentage of incidence (percentage of infected fruit with respect to total fruit number).

Statistical analysis. Data were analyzed using the General Linear Model and Regression Procedures from SAS (SAS Version 9.3; SAS Inst. Inc., Cary, NC). Data means were separated by Fisher's protected least significant difference test at $95 \%$ confidence. Percentages were transformed to arcsin values before analysis. For clarity, non-transformed percentage means were used for presentation in tables and figures. Because data for 2008 came from a single cultivar, they were analyzed independently. Data from 2009 and 2010 were pooled when no year $\times$ treatment interactions were found.

\section{Results and Discussion}

Microclimate. Maximal, mean, and minimal air temperatures for the season were $30.7,25.3$, and $19.8^{\circ} \mathrm{C}$ in $2008 ; 30.1,25.1$, and $20.0^{\circ} \mathrm{C}$ in 2009 ; and $32.0,26.8$, and $21.6^{\circ} \mathrm{C}$ in 2010, respectively. Under unshaded
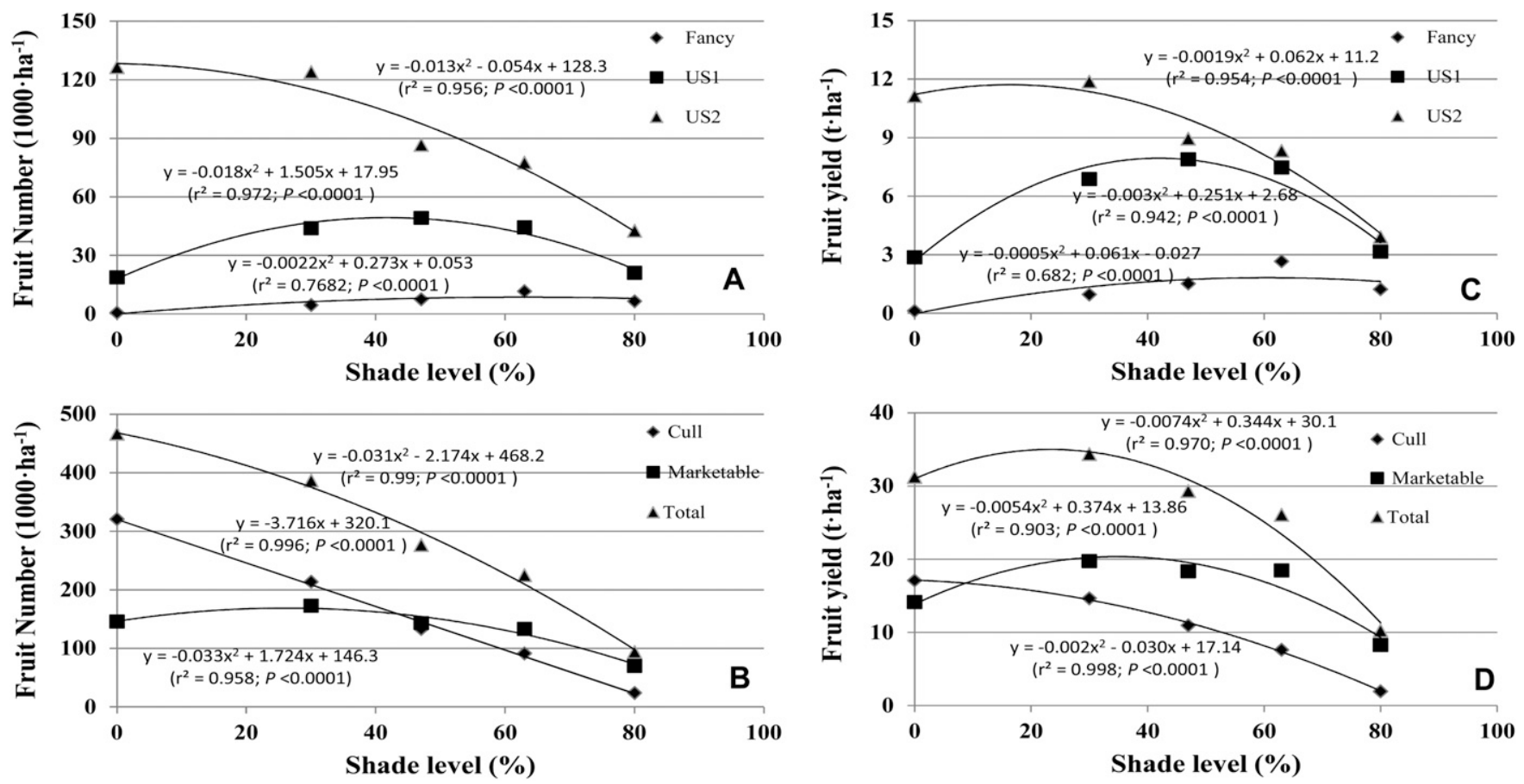

Fig. 3. Bell pepper fruit number (A-B) and fruit yield (C-D) in Tifton, GA, as a function of shade level under field conditions. Fruit were harvested at the ripe stage (turning or fully colored). Data from cvs. Camelot, Lafayette, Sirius, and Stiletto harvested in spring-summer of 2009 and 2010 were pooled. Photosynthetically active radiation $(P A R)$ on clear days was $\approx 2100 \mu \mathrm{mol} \cdot \mathrm{m}^{-2} \cdot \mathrm{s}^{-1}$ in Tifton, GA. 

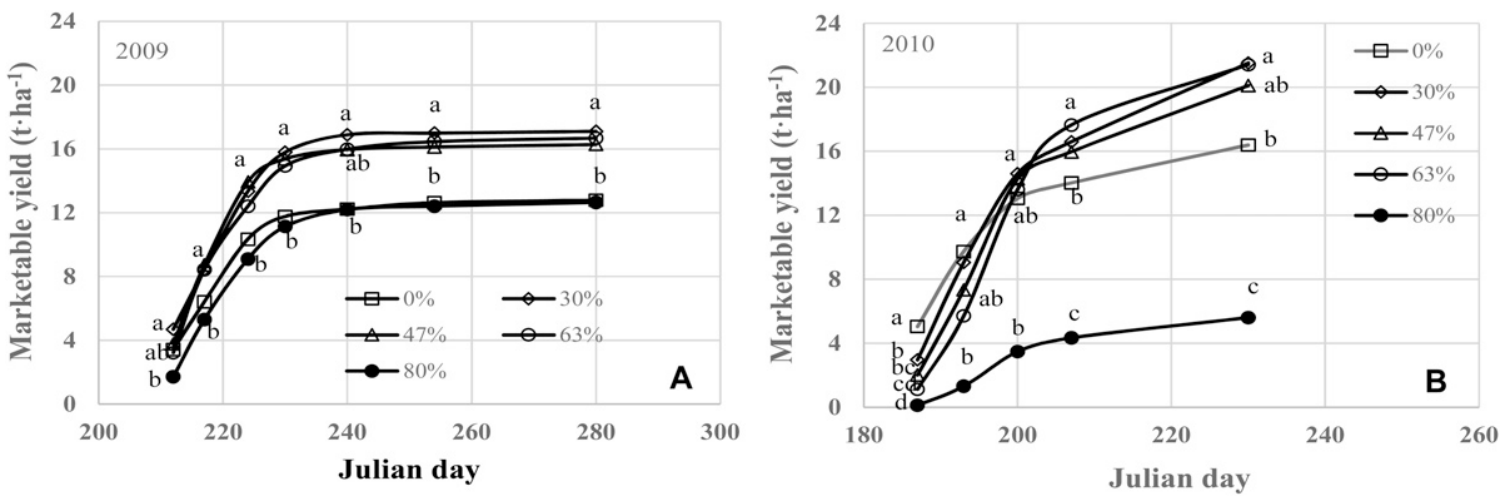

Fig. 4. Bell pepper cumulative marketable yield over time in 2009 (A) and 2010 (B) as affected by shade level. Fruit were harvested at the ripe stage (turning or fully colored). Data from cultivars Camelot, Lafayette, Sirius, and Stiletto were pooled. Photosynthetically active radiation $(P A R)$ on clear days was $\approx 2100$ $\mu \mathrm{mol} \cdot \mathrm{m}^{-2} \cdot \mathrm{s}^{-1}$ in Tifton, GA, spring-summer of 2009 and 2010.
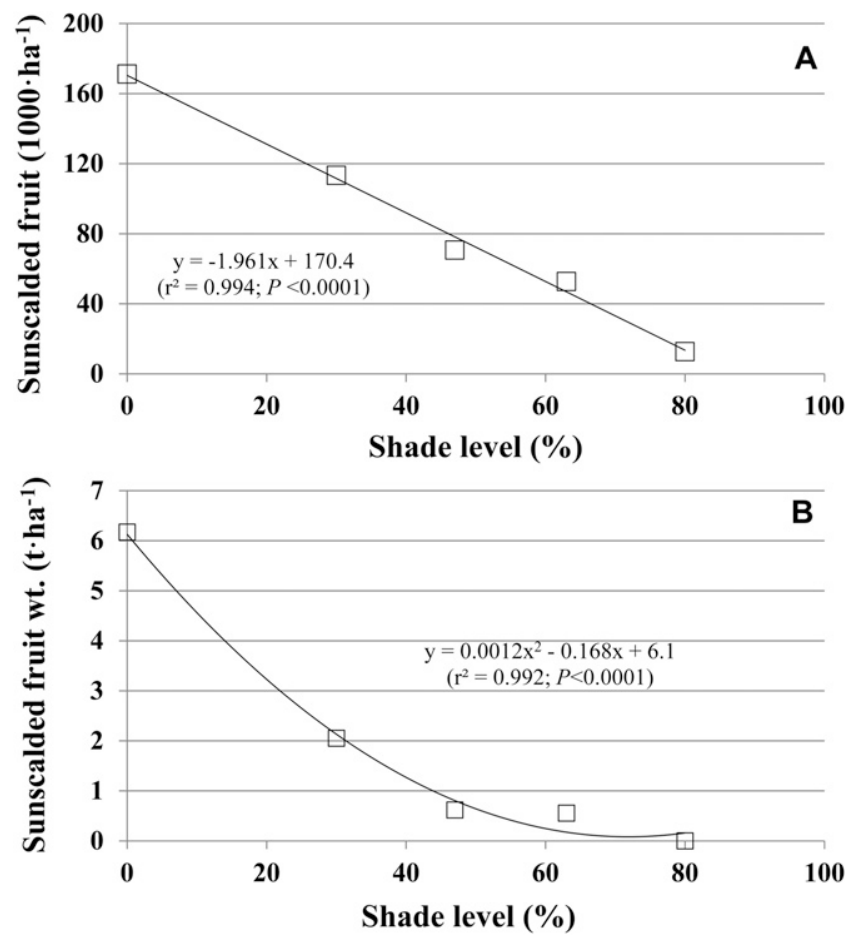

Fig. 5. Relationship between number (A) and weight (B) of sunscalded bell pepper fruit and shade level under field conditions. Fruit were harvested at the ripe stage (turning or fully colored). Data from cvs. Camelot, Lafayette, Sirius, and Stiletto were pooled. Photosynthetically active radiation $(P A R)$ on clear days was $\approx 2100 \mu \mathrm{mol} \cdot \mathrm{m}^{-2} \cdot \mathrm{s}^{-1}$ in Tifton, GA, spring-summer of 2009 and 2010 .

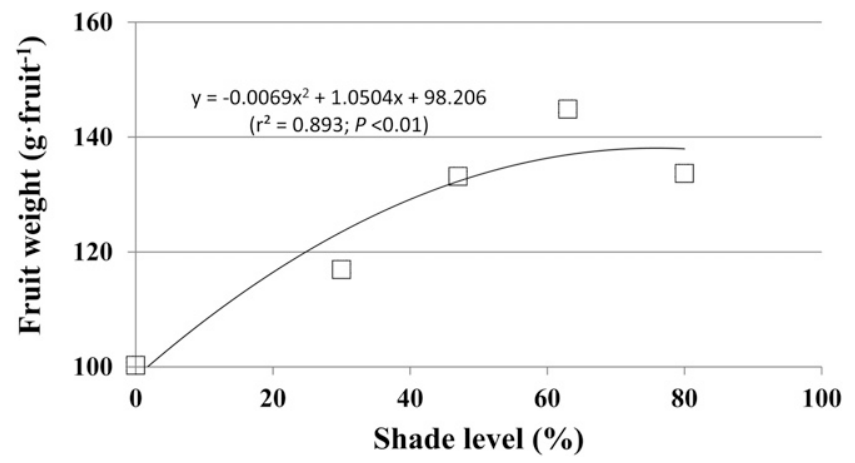

Fig. 6. Individual weight of marketable bell pepper fruit as a function of shade level under field conditions. Fruit were harvested at the ripe stage (turning or fully colored). Data from cvs. Camelot, Lafayette, Sirius, and Stiletto were pooled. Photosynthetically active radiation $(P A R)$ on clear days was $\approx 2100$ $\mu \mathrm{mol} \cdot \mathrm{m}^{-2} \cdot \mathrm{s}^{-1}$ in Tifton, GA, spring-summer of 2009 and 2010. conditions, $P A R$ in clear days was $\approx 2100$ $\mu \mathrm{mol} \cdot \mathrm{m}^{-2} \cdot \mathrm{s}^{-1}$. Photosynthetically active radiation, air temperature, leaf temperature, and root-zone temperature decreased linearly with increasing shade levels (Díaz-Pérez, 2013). These results are consistent with previous reports indicating that shading reduces solar radiation and air and soil temperatures (Allen, 1975; Kittas et al., 2012; Zhang, 2006).

Plant disease incidences. Incidence of Phytophthora blight decreased with increasing shade level in both 2009 and 2010 (Fig. 1). Among cultivars, incidence of Phytophthora blight was highest in 'Lafayette' (12.4\%) followed by 'Sirius' (10.0\%), 'Stiletto' $(8.0 \%)$, and 'Camelot' $(5.2 \%)$. Incidence of TSW was low in 2009 and 2010 and unaffected by shade level. Among cultivars, incidence of TSW was highest for 'Camelot' $(1.5 \%)$ followed by 'Lafayette' $(0.9 \%)$, 'Sirius' $(0 \%)$, and 'Stiletto' (0\%).

Soil microbial populations can be affected by changes in light level under natural conditions. Forests gaps are known to influence trophic interactions, including the microbial densities in the soil (Reinhart et al., 2010). To our knowledge, effects of artificial manipulation of light in the field on plant-pathogen interactions such as by use of shading nets have not been reported. In this study, shaded conditions reduced root zone temperature to a value closer to optimal root zone temperature $\left(\approx 27{ }^{\circ} \mathrm{C}\right)$ for bell pepper compared with unshaded conditions (Díaz-Pérez, 2013). Decreased disease associated with shading may be related to amelioration of heat stress of bell pepper plants. Tomato were found to have increased incidence of TSW associated with increased root zone temperature (Díaz-Pérez et al., 2006). Shading also reduced irradiation and, to a lesser degree, air temperature, leading to reduced plant transpiration and increased soil moisture (Díaz-Pérez, 2013). It is unclear whether increased incidence of Phytophthora blight under unshaded conditions was the result of an effect on the host, the pathogen, or their interaction with the environment. However, by reducing evaporative demand, shading likely provided some benefit to infected plants that had a limited capacity for water uptake and transport as a result of 

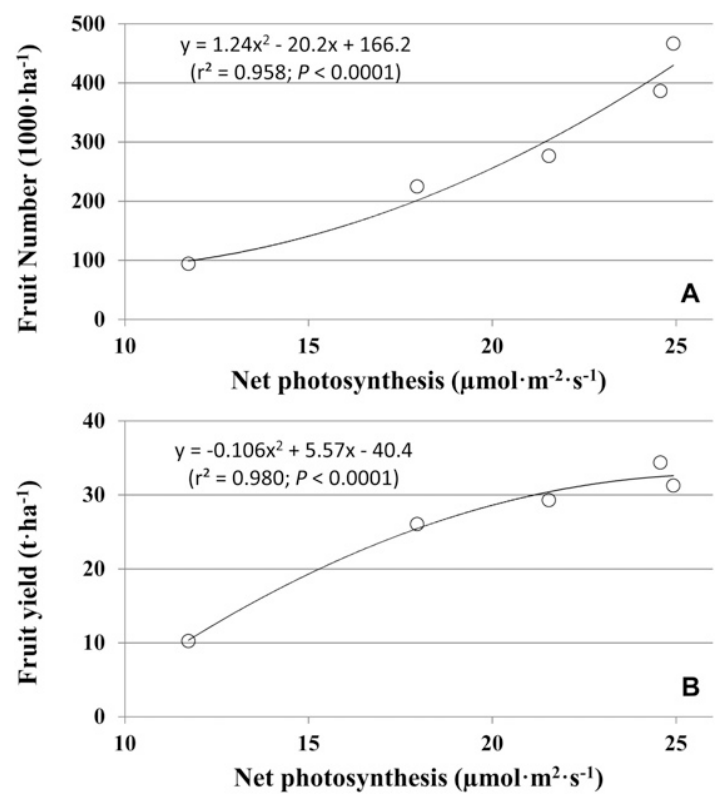

Fig. 7. Bell pepper fruit number (A) and fruit yield (B) as a function of leaf net photosynthesis under field conditions. Fruit were harvested at the ripe stage (turning or fully colored). Data from cvs. Camelot, Lafayette, Sirius, and Stiletto were pooled. Photosynthetically active radiation $(P A R)$ on clear days was $\approx 2100 \mu \mathrm{mol} \cdot \mathrm{m}^{-2} \cdot \mathrm{s}^{-1}$ in Tifton, GA, spring-summer of 2009 and 2010 .
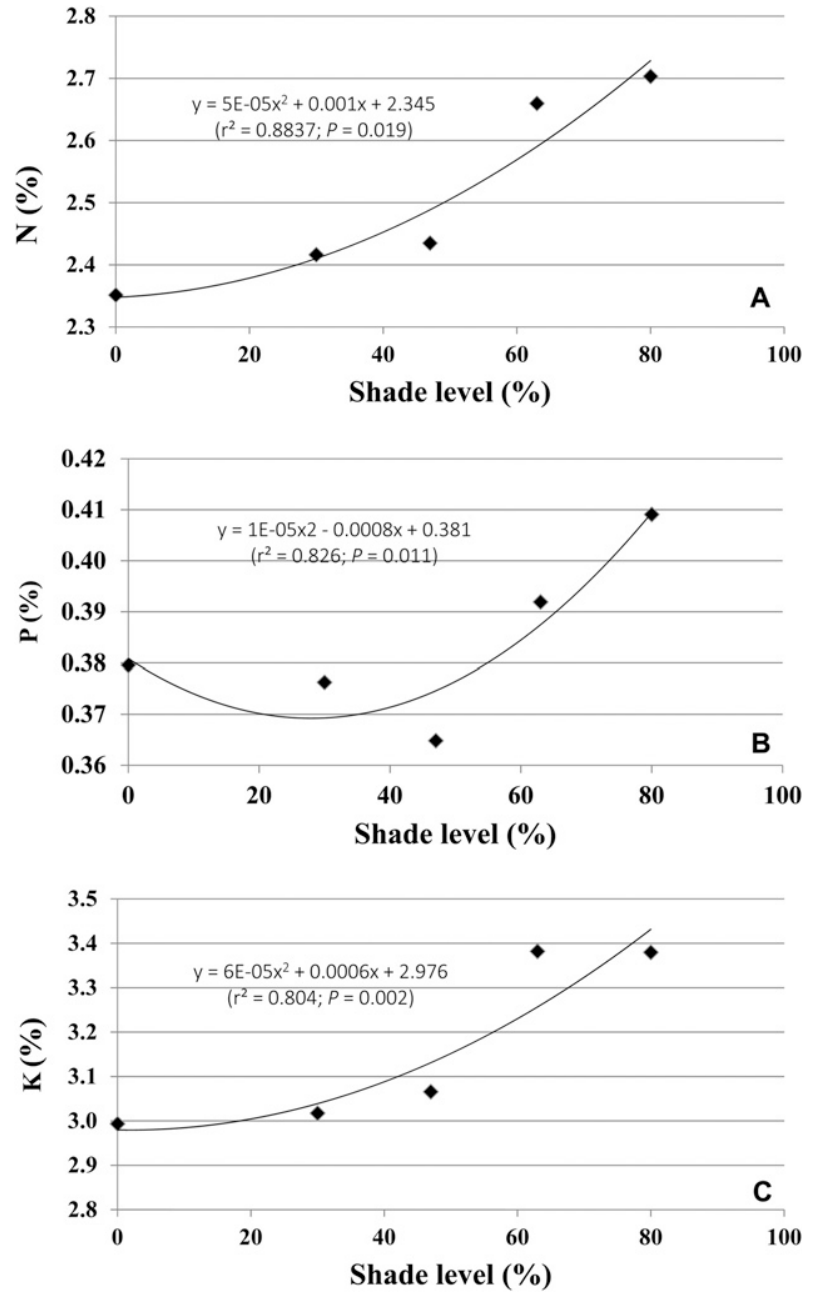

Fig. 8. Nitrogen (A), phosphorus $(\mathbf{B})$, and potassium $(\mathbf{C})$ concentrations of ripe bell pepper fruit as a function of shade level under field conditions. Fruit were harvested at the ripe stage (turning or fully colored). Data from cvs. Camelot, Lafayette, Sirius, and Stiletto were pooled. Photosynthetically active radiation $(P A R)$ on clear days was $\approx 2100 \mu \mathrm{mol} \cdot \mathrm{m}^{-2} \cdot \mathrm{s}^{-1}$ in Tifton, GA, spring-summer of 2009 and 2010 . a damaged vascular system (Aguirreolea et al., 1995). Reduced incidence of Phytophthora blight indicates that shading may be a tool to manage soilborne diseases in bell pepper and other crops.

Yields in 2008. Yields of mature green fruit of 'Heritage' were affected by shading level. Total and marketable fruit weight increased with shade level to a maximum at $27.6 \%$ and $34.3 \%$ shade, respectively, and then decreased with increasing shade level, whereas cull fruit weight and total fruit number decreased with increasing shade level (Fig. 2). Relative to unshaded plants, total and marketable yields were improved by up to $36 \%$ and $119 \%$, respectively. The percent of marketable fruit (relative to total) was higher in shaded compared with unshaded conditions with no difference among shade levels. Number of cull fruit (majority scalded) decreased with increasing shade level up to $47 \%$ shade and then remained about constant with further increases in shade level. Based on the improved yield and quality of mature green bell pepper and season extension under shading in 2008 , it was decided to evaluate the effect of shading on fruit yield and quality of ripe bell pepper fruit.

Yields in 2009 and 2010. Bell pepper yields and fruit weight were lower in 2009 than in $2010(P<0.01)$. There was a year-by-cultivar interaction for all yield variables except total number of fruit. Total number of fruit was highest for 'Stiletto' $(362,000$ fruit/ha) and total numbers in remaining cultivars were similar (mean $=290,000$ frui$\mathrm{t} / \mathrm{ha})$. Incidence of sunscald was highest in cvs. Lafayette $(36.5 \%)$ and Sirius $(37.2 \%)$ and lowest in Camelot $(24.6 \%)$ and Stiletto $(24.0 \%)$. Numbers of marketable fruit produced were highest in 'Stiletto' in 2009 and 'Camelot' in 2010 (Table 1). Marketable yield was highest in 'Camelot' and 'Stiletto' in 2009 and 'Camelot' and 'Lafayette' in 2010. Number of culls was highest in 'Sirius' (2009) and 'Stiletto' (2010), whereas cull weights were highest in 'Sirius' (2009) and 'Lafayette' (2010). Total fruit weight was similar among cultivars in 2009; it was highest in 'Lafayette' and lowest in 'Sirius' in 2010. Individual fruit weight was lowest in 'Stiletto' in both years.

In both 2009 and 2010, shading resulted in improved yield and quality of ripe bell pepper fruit (Fig. 3). Number of fruit with different marketable fruit grades varied in response to shade level. Number of Fancy, US1, and total marketable fruit increased to a maximum and declined with increasing shade level. Using the second derivatives from the equations in Figure 3, the calculated optimal shade levels were $62 \%, 42 \%$, and $26 \%$ for number of Fancy, US1, and marketable fruit, respectively. The number of US2, culls, and total fruit decreased with increasing shading. Yield of Fancy, US1, US2, total marketable, and total fruit yield improved with increased shading to a maximum and decreased with further increases in shade level. The calculated optimal shade levels were $61 \%, 42 \%$, and $35 \%$ for Fancy yield, US1 yield, and marketable yield, respectively. Relative to 
unshaded plants, total and marketable yields were improved by up to $10 \%$ and $43 \%$ by moderate shading, respectively.

In the first two harvests in 2009 and 2010 , the unshaded treatment yielded similarly as shade treatments $30 \%, 47 \%$, and $63 \%$, but as the season progressed, its fruit production decreased. In all treatments, production of marketable fruit was reduced after 18 Aug. 2009 (Julian Day 230) and 26 July 2010 (Julian Day 207) (Fig. 4). After these dates, supraoptimal temperatures affected fruit set, growth, and quality (Díaz-Pérez, 2010; Erickson and Markhart, 2001). Average maximal, mean, and minimal air temperatures during the period of fruit development before the last harvest of marketable fruit were 32.0, 27.0, and $22.0^{\circ} \mathrm{C}$ in 2009 and $33.3,28.1$, and $22.8^{\circ} \mathrm{C}$ in 2010 , respectively. Lowest cumulative marketable yields were observed at $0 \%$ shade and $80 \%$ shade in 2009 and $80 \%$ shade followed by $0 \%$ shade in 2010 .

Number of sunscalded fruit decreased with shade level (Fig. 5). Weight of sunscalded fruit decreased with shade level up to $47 \%$ shade and changed little with further increases in shade level. Sunscald was the major fruit preharvest defect, although blossom-end rot and decay (caused primarily by Colletotrichum spp.) were also present (data not shown). Like with sunscald, blossom-end rot and fruit decay declined with shade level.

Individual fruit weight improved with increasing shading level up to $47 \%$ shade and changed little at higher shade levels (Fig. 6). Increased fruit size was likely the result of reduced transpiration and improved plant water status and net photosynthesis under shaded conditions (Díaz-Pérez, 2013).

Total fruit number increased with increasing net photosynthesis (Fig. 7), indicating that fruit number is determined by assimilate availability. Total fruit yield increased with increasing net photosynthesis up to $\approx 22$ $\mu \mathrm{mol} \cdot \mathrm{m}^{-2} \cdot \mathrm{s}^{-1}$ and remained about constant with further increases in net photosynthesis. Net photosynthesis in bell pepper was shown to be maximal between and $0 \%$ shade $(P A R=$ $\left.2100 \mu \mathrm{mol} \cdot \mathrm{m}^{-2} \cdot \mathrm{s}^{-1}\right)$ and $30 \%$ shade $(P A R=$ $1470 \mu \mathrm{mol} \cdot \mathrm{m}^{-2} \cdot \mathrm{s}^{-1}$ ) (Díaz-Pérez, 2013).

Among cultivars, 'Camelot' produced among the highest number of marketable fruit and fruit yields (Table 1). 'Sirius' had the lowest number and yield of marketable fruit and greatest number of culls. 'Camelot' had the lowest number and yield of cull fruit. 'Stiletto' produced the greatest number of fruit, whereas 'Lafayette' the highest total fruit yield. 'Sirius' produced the heaviest fruit followed by 'Camelot', 'Lafayette', and 'Stiletto'. 'Lafayette' and 'Sirius' exhibited the greatest incidence of fruit sunscald. Net photosynthesis was highest in 'Camelot' and lowest in 'Lafayette' and 'Sirius'. Highest yields in 'Camelot' were likely the result of its highest rates of net photosynthesis (Díaz-Pérez, 2013).

Bell pepper present leaf and stem morphological and physiological adaptations in response to shade (Björkman, 1981). Bell pepper plant height, plant leaf area, individual leaf area, individual leaf dry weight, and leaf weight ratio (fraction of total above-ground biomass allocated to leaves) increased, whereas the specific leaf weight (leaf dry weight per unit leaf area, an estimator of leaf thickness) decreased with increased shade level (Díaz-Pérez, 2013). Shading affected both bell pepper fruit yield and quality (fruit grade). Moderate shading $(30 \%$ to $47 \%)$ increased total and marketable yields probably as a result of amelioration of heat stress (reduction in canopy and root zone temperatures) compared with unshaded plants. Excessive shading ( $80 \%$ shade) had the lowest bell pepper fruit yield as a result of reduced fruit number, which was probably associated with reduced photosynthesis and allocation of assimilates to fruits and increased allocation of assimilates to vegetative organs (Díaz-Pérez, 2013).

Variable responses of bell pepper yield to shade level may be attributed to the particular environmental conditions created by the shade net. Shading reduces $P A R$, which is necessary for photosynthesis; it also reduces IR radiation, which determines crop heating. Bell pepper showed no reduction in net photosynthetic rate $\left(\mathrm{P}_{\mathrm{n}}\right)$ with up to $30 \%$ shading (Díaz-Pérez, 2013). Increased shading above $30 \%$ level will further decrease IR radiation and will likely result in reduced $\mathrm{P}_{\mathrm{n}}$. Optimal shade level will be that which maximizes the cooling effect as a result of reduction of IR radiation and minimizes the reduction in $\mathrm{P}_{\mathrm{n}}$ resulting from reduction in $P A R$.

Studies around the world show positive effects of shading on bell pepper yield and quality. In Israel, bell pepper grown under $47 \%$ shade had a reduced number of fruit per plant in the summer, whereas at $25 \%$ shade, plants had increased flower drop in the winter. Shading led to increased yield of top quality fruit and during the summer reduced occurrence of sunscald (Rylski and Spigelman, 1986). Shaded bell pepper had increased yields and increased powdery mildew severity with disease being negatively associated with shading level (Elad et al., 2007). In Egypt, $63 \%$ shade level produced the highest bell pepper vegetative top fresh and dry weight, whereas $40 \%$ shade produced the highest total yield, average fruit weight, and number of marketable fruit (El-Aidy et al., 1993). In Serbia, bell pepper grown under colored nets with $40 \%$ or $50 \%$ shade had higher total yields compared with unshaded plants (Ilic et al., 2011). Beneficial effects (increased marketable
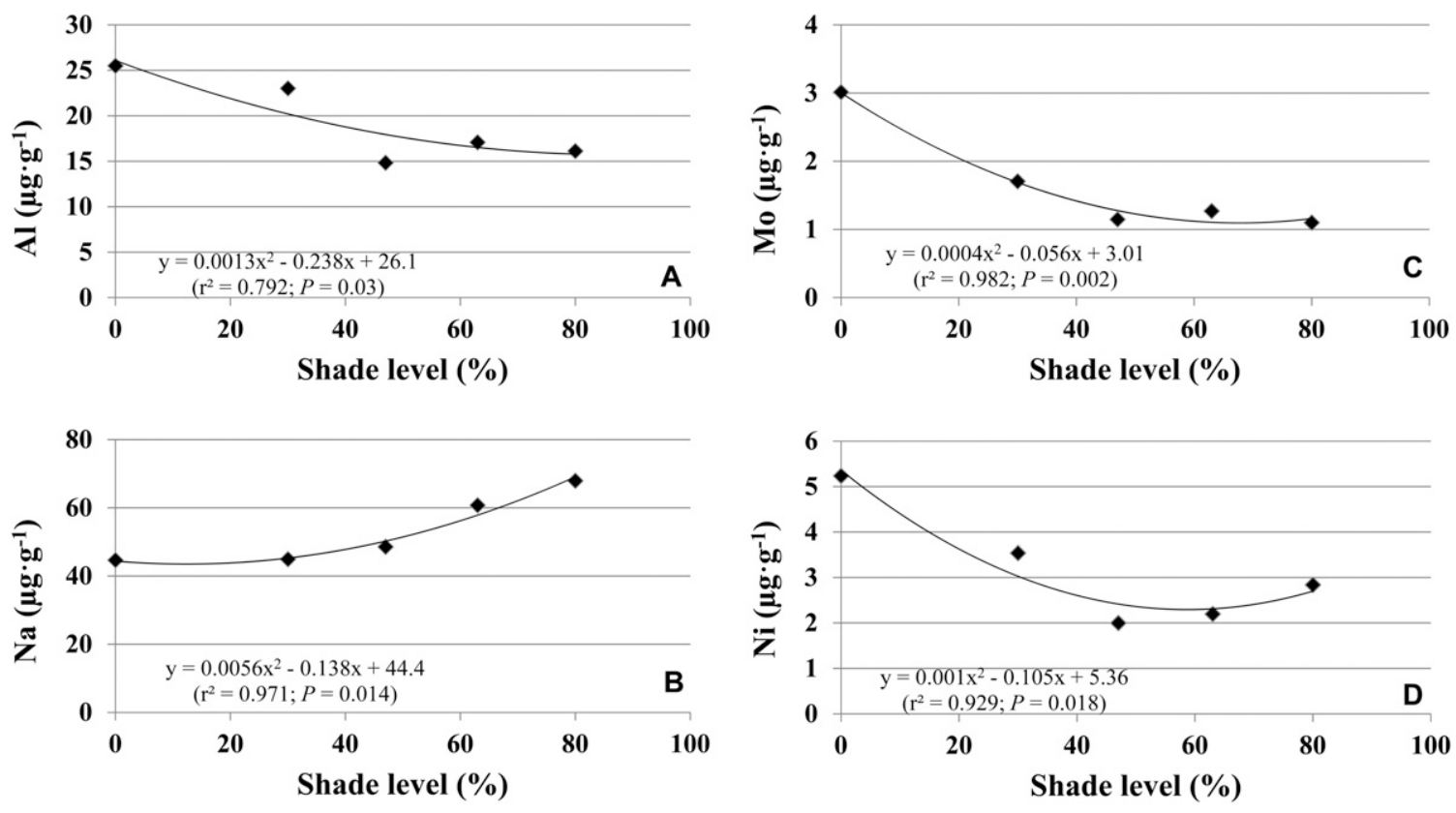

Fig. 9. Aluminum (A), sodium (B), molybdenum (C), and nickel (D) concentrations of ripe bell pepper fruit as a function of shade level under field conditions. Fruit were harvested at the ripe stage (turning or fully colored). Data from cvs. Camelot, Lafayette, Sirius, and Stiletto were pooled. Photosynthetically active radiation $(P A R)$ on clear days was $\approx 2100 \mu \mathrm{mol} \cdot \mathrm{m}^{-2} \cdot \mathrm{s}^{-1}$ in Tifton, GA, spring-summer of 2009 and 2010. 
yield and reduced incidence of sunscald) of shading are probably associated with a reduction in irradiation, air temperature, and soil temperature under shaded conditions resulting in amelioration of heat stress in the plants.

Sunscald is a solar radiation injury that causes fruit tissue necrosis or browning and is accompanied by changes in fruit pigments (Schrader, 2011). Bell pepper yellow fruit cultivars displayed greater incidence of sunscald than red fruit cultivars. This could be attributed to a likely increased concentration of carotenoids in red fruit cultivars. Carotenoids protect leaves and fruit tissues from photo-oxidative processes associated with sunscald disorder. In tomato, increased temperature and solar radiation diminish lycopene and $\beta$-carotene contents, resulting in induction of sunscald (Rosales et al., 2006).

Fruit mineral nutrients. Shade level affected bell pepper fruit mineral nutrient concentration but the effect differed among nutrients. Fruit N, P, and $\mathrm{K}$ concentrations increased with shade level, whereas those of $\mathrm{Ca}$, magnesium $(\mathrm{Mg})$, and $\mathrm{S}$ were unaffected (Fig. 8). Among micronutrients, Al, Mo, and Ni concentrations decreased and sodium $(\mathrm{Na})$ concentration increased with shade level (Fig. 9), whereas levels of boron (B), copper $(\mathrm{Cu})$, iron $(\mathrm{Fe})$, and $\mathrm{Zn}$ were unaffected. Fruit nutrient concentrations were lower in 2009 , except for concentrations of $\mathrm{Ca}, \mathrm{Mg}$, and $\mathrm{Cu}$, which were higher in 2009 than in 2010; $\mathrm{B}$ and $\mathrm{Fe}$ levels were similar between years (Table 2). Reduced fruit yields were probably associated with decreased nutrient levels (2009). Cultivars differed in fruit mineral nutrient concentrations. 'Lafayette' had the highest fruit concentration of $\mathrm{N}, \mathrm{Ca}, \mathrm{S}, \mathrm{Mn}$, and Zn; 'Camelot', 'Sirius', and 'Stiletto' did not differ in concentrations for those nutrients (Table 2). There were no year $\times$ cultivar interactions for fruit nutrients, except for $\mathrm{S}$, $\mathrm{Fe}$, and $\mathrm{Mn}$.

There are few studies on the effect of shading on mineral nutrition of vegetable crops. In greenhouse tomato, there was a linear decline in water, $\mathrm{N}$ and $\mathrm{K}$ uptake, and increase in foliar concentration of $\mathrm{N}, \mathrm{P}$, and $\mathrm{K}$ with increasing shade level; however, fruit mineral nutrient content was not tested (Gent, 2008). Shading increased foliar concentration of $\mathrm{N}, \mathrm{P}$, and $\mathrm{K}$ in tomato (Liu et al., 2003). In bell pepper, shading was found to augment mineral nutrient concentrations in shaded leaves (Díaz-Pérez, 2013). Augmented foliar nutrient levels with increased shading are consistent with the increased bell pepper fruit levels of $\mathrm{N}, \mathrm{P}, \mathrm{K}$, and $\mathrm{Na}$ with increased shade level (Fig. 8).

Humans require more than 22 mineral elements, which can all be supplied by an appropriate diet. Diets often lack $\mathrm{Ca}, \mathrm{Mg}, \mathrm{Cu}$, Shading had no effect on bell pepper fruit concentration of these elements important for human nutrition.

Postharvest. Fruit water loss rate (mean = $0.87 \% /$ day) was unaffected by shade level (Table 3). Fruit dry weight percent and $\mathrm{Fe}$, and $\mathrm{Zn}$ (White and Broadley, 2005).

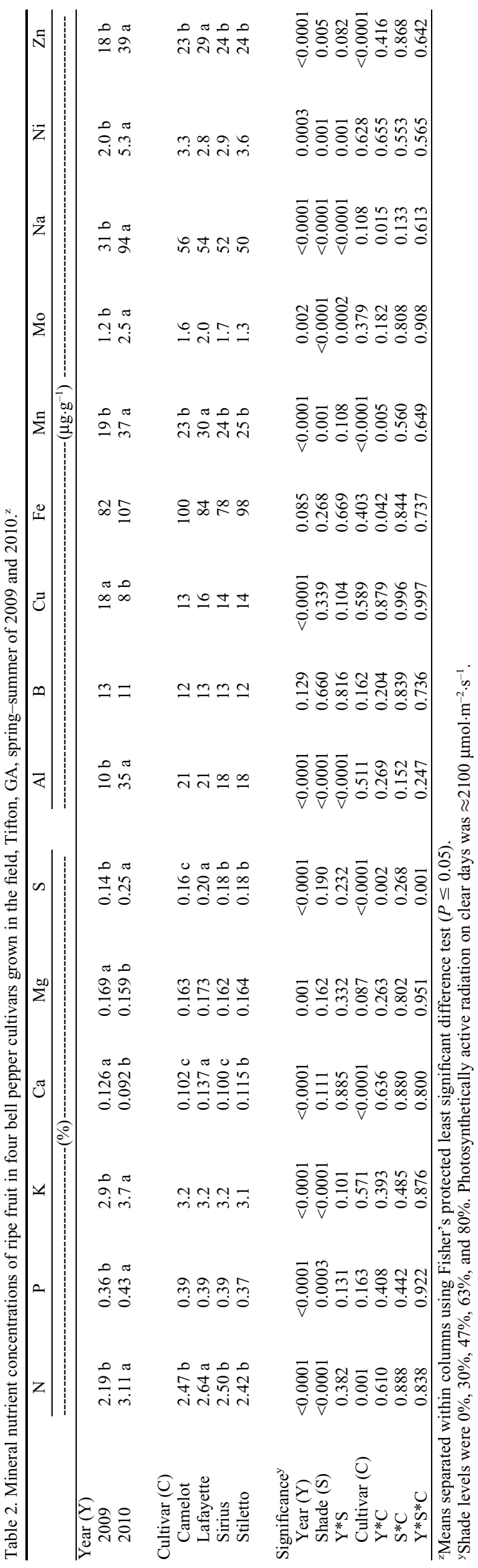

HortScience Vol. 49(7) July 2014 
Table 3. Postharvest attributes of ripe bell pepper fruit as affected by cultivar, Tifton, GA, spring and summer of 2009 and 2010 , z,y

\begin{tabular}{lcccc}
\hline Cultivar & WLR (\%/day) & Fruit $\mathrm{DW}^{\mathrm{y}}(\%)$ & $\mathrm{SSC}^{\mathrm{y}}(\%)$ & $\begin{array}{c}\text { Incidence of bacterial } \\
\text { soft rot }^{\mathrm{y}}(\%)\end{array}$ \\
\hline Camelot & $0.755 \mathrm{c}^{\mathrm{x}}$ & $7.5 \mathrm{a}$ & $5.4 \mathrm{~b}$ & $14 \mathrm{~b}$ \\
Lafayette & $0.866 \mathrm{~b}$ & $6.5 \mathrm{~b}$ & $5.2 \mathrm{~b}$ & $33 \mathrm{a}$ \\
Sirius & $0.972 \mathrm{a}$ & $6.8 \mathrm{~b}$ & $5.9 \mathrm{a}$ & $29 \mathrm{a}$ \\
Stiletto & $0.878 \mathrm{ab}$ & $6.9 \mathrm{~b}$ & $5.8 \mathrm{a}$ & $4 \mathrm{~b}$ \\
& & & & \\
Significance & & & $\mathrm{ND}$ & $\mathrm{ND}$ \\
Year (Y) & $<0.0001$ & $\mathrm{ND}^{\mathrm{w}}$ & 0.022 & 0.121 \\
Shade (S) & $0.193^{\mathrm{v}}$ & 0.0003 & $\mathrm{ND}$ & $\mathrm{ND}$ \\
$\mathrm{Y}^{*} \mathrm{~S}$ & 0.665 & 0.0004 & 0.087 & $<0.0001$ \\
Cultivar (C) & 0.009 & $\mathrm{ND}$ & $\mathrm{ND}$ & $\mathrm{ND}$ \\
$\mathrm{Y}^{*} \mathrm{C}$ & 0.804 & 0.055 & 0.376 & 0.012 \\
$\mathrm{~S}^{*} \mathrm{C}$ & 0.988 & $\mathrm{ND}$ & $\mathrm{ND}$ & $\mathrm{ND}$ \\
$\mathrm{Y}^{*} \mathrm{~S}^{*} \mathrm{C}$ & 0.923 & & & \\
\hline
\end{tabular}

${ }^{\text {}}$ Fruit kept at $20{ }^{\circ} \mathrm{C}$, vapor pressure difference of $1.50 \mathrm{kPa}$, and air velocity of less than $0.2 \mathrm{~m} \cdot \mathrm{s}^{-1}$.

${ }^{\mathrm{y}} \mathrm{WLR}=$ water loss rate; fruit DW $(\%)=[(\mathrm{DW} / \mathrm{FW}) * 100] ; \mathrm{DW}=$ fruit dry weight; $\mathrm{FW}=$ fruit fresh weight; $\mathrm{SSC}=$ soluble solids concentration; incidence of bacterial soft rot is the percentage of fruit with bacterial soft rot symptoms (caused by Erwinia spp.) relative to total fruit number. Fruit DW percentage and SSC were measured immediately after harvest. Fruit WLR and bacterial soft rot incidence were determined after the 7-d keeping period. WLR was measured in 2009 and 2010; bacterial soft rot incidence in 2009 only; and SSC and percentage of fruit dry weight in 2010 only.

${ }^{\mathrm{x}}$ Means separated within columns using Fisher's protected least significant difference test $(P \leq 0.05)$. ${ }^{\mathrm{w}} \mathrm{ND}=$ not determined.

v'Shade levels were $0 \%, 30 \%, 47 \%, 63 \%$, and $80 \%$. Photosynthetically active radiation on clear days was $\approx 2100 \mu \mathrm{mol} \cdot \mathrm{m}^{-2} \cdot \mathrm{s}^{-1}$.
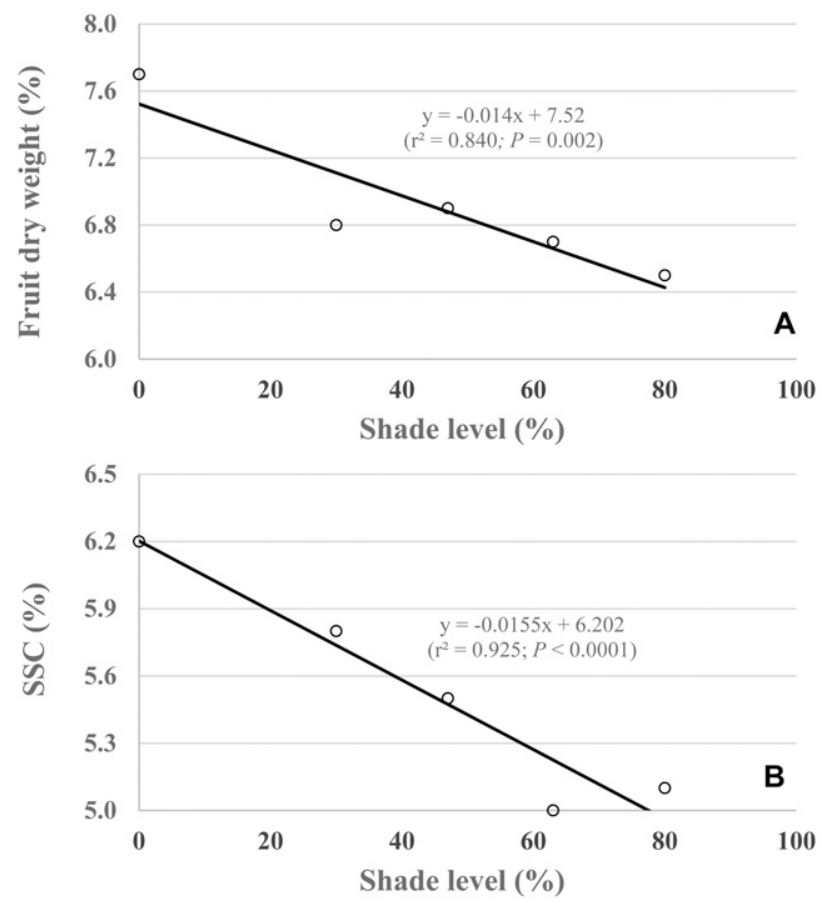

Fig. 10. Percentage of dry weight (A) and soluble solids concentration (B) in ripe bell pepper fruit as a function of shade level under field conditions. Fruit were harvested at the ripe stage (turning or fully colored). Data from cvs. Camelot, Lafayette, Sirius, and Stiletto were pooled. Photosynthetically active radiation $(P A R)$ on clear days was $\approx 2100 \mu \mathrm{mol} \cdot \mathrm{m}^{-2} \cdot \mathrm{s}^{-1}$ in Tifton, GA, spring-summer of 2009 and 2010.

Table 4. Incidence of bacterial soft rot as affected by shade level in ripe fruit of four bell pepper cultivars, Tifton, GA, summer of 2010, z,y

\begin{tabular}{lcccc}
\hline & \multicolumn{4}{c}{ Incidence of bacterial soft rot (\%) } \\
\cline { 2 - 5 } Shade (\%) & Camelot & Lafayette & Sirius & Stiletto \\
\hline 0 & $8 \mathrm{bc}$ & $19 \mathrm{~b}$ & $20 \mathrm{~b}$ & 11 \\
30 & $24 \mathrm{a}$ & $23 \mathrm{~b}$ & $34 \mathrm{ab}$ & 8 \\
47 & $20 \mathrm{ab}$ & $19 \mathrm{~b}$ & $55 \mathrm{a}$ & 8 \\
63 & $20 \mathrm{ab}$ & $66 \mathrm{a}$ & $19 \mathrm{~b}$ & 0 \\
80 & $0 \mathrm{c}$ & $32 \mathrm{ab}$ & $16 \mathrm{~b}$ & 0 \\
Significance & 0.013 & 0.019 & 0.004 & 0.307 \\
\hline & ${ }^{2}$ Means separated within columns using Fisher's protected least significant difference test $(P \leq 0.05)$. \\
&
\end{tabular}

soluble solids concentration (SSC) decreased with shade level (Fig. 10). Among cultivars, fruit $W L R$ was highest in 'Sirius' and lowest in 'Camelot' (Table 3). Fruit dry weight percent was highest in 'Camelot' and similar among the other cultivars. Soluble solids concentration was highest in 'Sirius' and 'Stiletto'. Across cultivar and shade treatments, ripe bell pepper fruit had reduced SSC (mean = $5.6 \%$ ), possibly as a result of high fruit respiration caused by high air temperatures during the summer. In another study, ripe bell pepper fruit had a SSC of $7.9 \%$ (Fox et al., 2005).

Bacterial soft rot incidences $($ mean $=20 \%)$ were highest at intermediate shade levels in all cultivars, except in 'Stiletto' (Table 4). Cultivars had no linear or quadratic relationship of bacterial soft rot incidence with shade level, except in 'Camelot', which had a quadratic relationship $(P=0.022)$. Bacterial soft rot incidences were highest in 'Lafayette' and 'Sirius', the yellow cultivars, and lowest in 'Camelot' and 'Stiletto', the red cultivars.

Shade affected fruit skin color differently among cultivars. Fruit $\mathrm{L}^{*}$ value increased in 'Camelot' and decreased in 'Lafayette' with increased shade level (Table 5). Fruit a* value decreased in 'Lafayette' and 'Sirius' with increased shade level. Fruit $b^{*}$ value increased in 'Camelot' and decreased in 'Lafayette' and 'Sirius' with increased shade level.

Bell pepper fruit epidermis lack stomata and water loss is primarily through the cuticle (Díaz-Pérez et al., 2007). Light and temperature can affect cuticle morphology, composition, and quality (Hull et al., 1975). Rate of fruit water loss or transpiration can differ among species and cultivars (Ben-Yehoshua and Weichmann, 1987; Lownds et al., 1993, 1994; Parsons et al., 2013). A high rate of fruit water loss may be associated with reduced shelf life as a result of fruit softening (Ben-Yehoshua and Weichmann, 1987). Bell pepper fruit $W L R$ declines with increased fruit size and as ripening progresses (Díaz-Pérez et al., 2007). Some factors affecting fruit transpiration are fruit surface area/volume or surface area/mass ratio (Ben-Yehoshua and Weichmann, 1987; Díaz-Pérez, 1998), structure of fruit surface, including number and size of stomata and lenticels, and the thickness and composition of the cuticle (Ben-Yehoshua and Weichmann, 1987; Lownds et al., 1993). In bell pepper, fruit transpiration is influenced by cuticle composition more than by cuticle amount (Parsons et al., 2012). Lack of effect of shading on bell pepper fruit $W L R$ indicates that shading had no effect on fruit cuticular conductance to water vapor. It is not possible to ascertain from this study, however, whether shade levels had any effects on cuticle amount or composition.

Shade nets may improve not only yield and quality, but also postharvest shelf life of bell pepper. Yellow shade netting was found to maintain bell pepper fruit quality and reduce decay incidence during storage (Fallik, 2009). For bell pepper, compared with black net, pearl net reduced $W L R$, decay incidence, 
Table 5. Skin color of ripe bell pepper fruit as affected by shade level and cultivar, Tifton, GA, summer of 2010 . $^{2}$

\begin{tabular}{|c|c|c|c|c|c|c|c|c|c|c|c|c|}
\hline \multirow[b]{2}{*}{ Shade (\%) } & \multicolumn{3}{|c|}{ Camelot } & \multicolumn{3}{|c|}{ Lafayette } & \multicolumn{3}{|c|}{ Sirius } & \multicolumn{3}{|c|}{ Stiletto } \\
\hline & $\mathrm{L}^{*}$ & $a^{*}$ & $b^{*}$ & $\mathrm{~L}^{*}$ & $\mathrm{a}^{*}$ & $b^{*}$ & $\mathrm{~L}^{*}$ & $\mathrm{a}^{*}$ & $b^{*}$ & $\mathrm{~L}^{*}$ & $a^{*}$ & $b^{*}$ \\
\hline 0 & 32.9 & 27.1 & 14.4 & 54.9 & 4.4 & 49.7 & 52.9 & 5.6 & 46.6 & 35.8 & 28.2 & 18.3 \\
\hline 30 & 33.2 & 26.3 & 14.5 & 54.7 & 2.4 & 48.6 & 51.1 & 1.4 & 43.3 & 35.4 & 28.7 & 17.4 \\
\hline 47 & 34.2 & 25.7 & 15.7 & 55.4 & 0.9 & 48.8 & 51.2 & 1.2 & 43.9 & 36.2 & 26.6 & 19.2 \\
\hline 63 & 35.0 & 26.1 & 16.8 & 54.2 & 1.5 & 47.6 & 50.3 & 0.4 & 41.9 & 35.3 & 28.3 & 17.3 \\
\hline 80 & 35.5 & 26.8 & 17.6 & 51.6 & 0.3 & 43.1 & 50.4 & -0.5 & $42.5 b$ & 36.8 & 27.9 & 19.2 \\
\hline $\mathrm{L}$ & $<0.0001$ & 0.428 & $<0.0001$ & 0.007 & $<0.0001$ & 0.0002 & 0.0005 & $<0.0001$ & $<0.0001$ & 0.491 & 0.689 & 0.700 \\
\hline Q & $<0.0001$ & 0.124 & $<0.0001$ & 0.0001 & $<0.0001$ & $<0.0001$ & 0.002 & $<0.0001$ & 0.0001 & 0.527 & 0.835 & 0.814 \\
\hline & & & & & Significance & & $\mathrm{L}^{*}$ & $a^{*}$ & $\mathrm{~b}^{*}$ & & & \\
\hline & & & & & Shade (S) & & 0.205 & $<0.0001$ & 0.014 & & & \\
\hline & & & & & Cultivar (C) & & $<0.0001$ & $<0.0001$ & $<0.0001$ & & & \\
\hline & & & & & $\mathrm{S} * \mathrm{C}$ & & $<0.0001$ & 0.002 & $<0.0001$ & & & \\
\hline
\end{tabular}

${ }^{ } \mathrm{L}=$ linear; $\mathrm{Q}=$ quadratic response.

and titratable acidity and increased fruit firmness, ascorbic acid content, and antioxidant activity (Kong et al., 2013).

In a greenhouse study using aluminized screens at $40 \%, 50 \%$, or $60 \%$ shade level, tomato plants under $60 \%$ shading had fruit with reduced SSC and increased firmness (Callejón-Ferre et al., 2009). Similarly, shading was reported to decrease SSC and incidence of fruit cracking and increase titratable acidity in tomato (Wada et al., 2006). Decreases in fruit dry weight percent with shade level indicate that fruit had reduced specific fruit weight (fruit dry weight per unit fruit surface area) or a thinner pericarp or that fruit may have undergone changes in cell structure or cell size under shade. In bell pepper, individual leaf area increased and specific leaf weight decreased with increased shade level (Díaz-Pérez, 2013). The decline in SSC with increased shade level may be a result of dilution effect caused by a possible increased fruit and whole-plant water status as a result of decreased plant and fruit transpiration under shaded conditions.

Red bell pepper fruit cultivars (Camelot and Stiletto) had higher a* values compared with yellow fruit cultivars (Lafayette and Sirius), indicating there were increased carotenoid levels in red fruit cultivars (Itle and Kabelka, 2009). Decreased a* and $b^{*}$ values with increasing shade levels in 'Lafayette' and 'Sirius' may indicate that carotenoids were decreased with increased shade level.

In summary, shade level affected fruit yield and quality and postharvest attributes of both mature green and ripe bell pepper fruit. Marketable yield improved with increased shading to a maximum at $\approx 35 \%$ shade and then decreased with further increases in shade level. Weight of individual marketable fruit increased with increasing shade level up to $47 \%$ shade and changed little at higher shade levels. Bell pepper yields depend on total number of fruit and fruit size. Number of fruit produced declined with increasing shade level. Thus, increased total fruit yield under moderate shading was caused by increased fruit size. Increased marketable fruit yield was also caused by increased fruit size, but it was also strongly determined by reduction in number of cull fruit, which resulted in increased percent of marketable fruit relative to total fruit number. Increased shade level was associated with reduced incidences of Phytophthora blight and fruit sunscald. Shade level affected bell pepper fruit mineral nutrient concentration but the effect differed among nutrients. Fruit water loss rate and bacterial soft rot incidence were unaffected by shade, whereas fruit dry weight percent and SSC decreased with shade level. Optimal shade level for maximal fruit yield and quality of bell pepper was between $30 \%$ and $47 \%$.

\section{Literature Cited}

Aguirreolea, J., J. Irigoyen, M. Sanchezdiaz, and J. Salaverri. 1995. Physiological alterations in pepper during wilt induced by Phytophthora capsici and soil water deficit. Plant Pathol. 44:587-596.

Allen, L.H., Jr. 1975. Shade-cloth microclimate of soybeans. Agron. J. 67:175-181.

Ben-Yehoshua, S. and J. Weichmann. 1987. Transpiration, water stress, and gas exchange, p. 113-170. Postharvest physiology of vegetables. Marcel Dekker, New York, NY.

Björkman, O. 1981. Response to different quantum flux densities, p. 57-107. In: Lange, O.L., P.S. Nobel, C.B. Osmond, and H. Ziegler (eds.). Physiological plant ecology. Responses to the physical environment. Springer-Verlag, Berlin, Germany.

Boyhan, G., J. Díaz-Pérez, C. Riner, R. Hill, and D. Thigpen. 2008. Evaluation of bell pepper and tomato varieties with and without shade. HortScience 43:1256.

Callejón-Ferre, A.J., F. Manzano-Agugliaro, M. DíazPérez, A. Carreno-Ortega, and J. Pérez-Alonso. 2009. Effect of shading with aluminised screens on fruit production and quality in tomato (Solanum lycopersicum L.) under greenhouse conditions. Span. J. Agr. Res. 7:41-49.

Castellano, S., G.S. Mugnozza, G. Russo, D. Briassoulis, A. Mistriotis, S. Hemming, and D. Waaijenberg. 2008. Plastics net in agriculture: A general review of types and applications. Appl. Eng. Agr. 24:799-808.

Deli, J. and H. Tiessen. 1969. Interaction of temperature and light intensity on flowering of Capsicum frutescens var. grossum cv. California Wonder. J. Amer. Soc. Hort. Sci. 40:493-497.

Díaz-Pérez, J.C. 1998. Transpiration rates in eggplant fruit as affected by fruit and calyx size. Postharvest Biol. Technol. 13:45-49.

Díaz-Pérez, J.C. 2010. Bell pepper (Capsicum annum L.) grown on plastic film mulches: Effects on crop microenvironment, physiological attributes, and fruit yield. HortScience 45:1196-1204.
Díaz-Pérez, J.C. 2013. Bell pepper (Capsicum annum L.) crop as affected by shade level: Microenvironment, plant growth, leaf gas exchange, and leaf mineral nutrient concentration. HortScience 48:175-182.

Díaz-Pérez, J.C., R. Gitaitis, and B. Mandal. 2006. Root zone temperature as modified by plastic mulches affect the appearance of first systemic symptoms of tomato spotted wilt and fruit yield in tomato. HortScience 41:1005-1006.

Díaz-Pérez, J.C., M.D. Muy-Rangel, and A.G. Mascorro. 2007. Fruit size and stage of ripeness affect postharvest water loss in bell pepper fruit (Capsicum annuиm L.). J. Sci. Food Agr. 87:68-73.

Dorland, R.E. and F.W. Went. 1947. Plant growth and controlled conditions. VIII. Growth and fruiting of the chili pepper (Capsicum annuиm). Amer. J. Bot. 34:393-401.

El-Aidy, F., M. El-Afry, and F. Ibraheim. 1993. Effect of shade and fertilizer levels and their interaction on fruit yield of sweet pepper. Acta Agron. Hung. 42:59-67.

Elad, Y., Y. Messika, M. Brand, D.R. David, and A. Sztejnberg. 2007. Effect of colored shade nets on pepper powdery mildew (Leveillula taurica). Phytoparasitica 35:285-299.

Erickson, A.N. and A.H. Markhart. 2001. Flower production, fruit set, and physiology of bell pepper during elevated temperature and vapor pressure deficit. J. Amer. Soc. Hort. Sci. 126:697-702.

Fallik, E. 2009. Can colored shade nets maintain sweet pepper quality during storage and marketing? Acta Hort. 830:37-44.

Fox, A.J., D. Del Pozo-Insfran, J.H. Lee, S.A. Sargent, and S.T. Talcott. 2005. Ripeninginduced chemical and antioxidant changes in bell peppers as affected by harvest maturity and postharvest ethylene exposure. HortScience 40:732-736.

Gent, M.P.N. 2008. Density and duration of shade affect water and nutrient use in greenhouse tomato. J. Amer. Soc. Hort. Sci. 133:619-627.

Hochmuth, R.C., D. Treadwell, E.H. Simone, L. Landrum, W.L. Laughlin, and L.L. Davis. 2013. Growing bell peppers in soilless culture under open shade structures. University of Florida, IFAS Extension.

Hull, H.M., H.L. Morton, and J.R. Wharrie. 1975. Environmental influences on cuticle development and resultant foliar penetration. Bot. Rev. 41:421-451.

Ilic, Z., L. Milenzovic, M. Duriovka, and N. Kapoulas. 2011. The effect of color shade nets on the greenhouse climate and pepper yield. 46th Croatian and 6th Intl. Symp. Agr., Opatija, Croatia.

Ilic, Z.S., L. Milenkovic, L. Stanojevic, D. Cvetkovic, and E. Fallik. 2012. Effects of the modification of 
light intensity by color shade nets on yield and quality of tomato fruits. Sci. Hort. 139:90-95.

Itle, R.A. and E.A. Kabelka. 2009. Correlation between $\mathrm{L}^{*} \mathrm{a}{ }^{*} \mathrm{~b}$ color space values and carotenoid content in pumpkins and squash (Cucurbita spp.). HortScience 44:633-637.

Kittas, C., N. Katsoulas, N. Rigakis, T. Bartzanas, and E. Kitta. 2012. Effects on microclimate, crop production and quality of a tomato crop grown under shade nets. J. Hort. Sci. Biotechnol. 87:7-12.

Kong, Y., L. Avraham, Y. Perzelan, S. Alkalai-Tuvia, K. Ratner, Y. Shahak, and E. Fallik. 2013. Pearl netting affects postharvest fruit quality in 'Vergasa' sweet pepper via light environment manipulation. Sci. Hort. 150:290-298.

Liu, X.Z., S.Z. Kang, H.P. Yi, and J.H. Zhang. 2003. Dry-matter partitioning, yield and leaf nutrient contents of tomato plants as influenced by shading at different growth stages. Pedosphere 13:263-270.

Lownds, N.K., M. Banaras, and P.W. Bosland. 1993. Relationships between postharvest water-loss and physical-properties of pepper pruit (Capsicum annuum L.). HortScience 28:1182-1184.

Lownds, N.K., M. Banaras, and P.W. Bosland. 1994. Postharvest water-loss and storage quality of nine pepper (Capsicum) cultivars. HortScience 29:191-193.
Moller, M. and S. Assouline. 2007. Effects of a shading screen on microclimate and crop water requirements. Irrig. Sci. 25:171-181.

Olle, M. and I. Bender. 2009. Causes and control of calcium deficiency disorders in vegetables: A review. J. Hort. Sci. Biotechnol. 84:577-584.

Parsons, E.P., S. Popopvsky, G.T. Lohrey, S. AlkalaiTuvia, Y. Perzelan, P. Bosland, P.J. Bebeli, I. Paran, E. Fallik, and M.A. Jenks. 2013. Fruit cuticle lipid composition and water loss in a diverse collection of pepper (Capsicum). Physiol. Plant. 149:160-174.

Parsons, E.P., S. Popopvsky, G.T. Lohrey, S.Y. Lu, S. Alkalai-Tuvia, Y. Perzelan, I. Paran, E. Fallik, and M.A. Jenks. 2012. Fruit cuticle lipid composition and fruit post-harvest water loss in an advanced backcross generation of pepper (Capsicum sp.). Physiol. Plant. 146:15-25.

Reinhart, K.O., A.A. Royo, S.A. Kageyama, and K. Clay. 2010. Canopy gaps decrease microbial densities and disease risk for a shadeintolerant tree species. Acta Oecol.-Intl. J. Ecol. 36:530-536.

Roberts, B.W. and J.A. Anderson. 1994. Canopy shade and soil mulch affect yield and solar injury of bell pepper. HortScience 29:258-260.

Rosales, M.A., J.M. Ruiz, J. Hernandez, T. Soriano, N. Castilla, and L. Romero. 2006. Antioxidant content and ascorbate metabolism in cherry tomato exocarp in relation to temperature and solar radiation. J. Sci. Food Agr. 86:1545-1551.

Russo, V.M. 1993. Shading of tomato plants inconsistently affects fruit yield. HortScience 28:1133.

Rylski, I. and M. Spigelman. 1986. Effect of shading on plant development, yield and fruit quality of sweet pepper grown under conditions of high temperature and radiation. Sci. Hort. 29:31-35.

Schrader, L.E. 2011. Scientific basis of a unique formulation for reducing sunburn of fruits. HortScience 46:6-11.

Taylor, M.D. and S.J. Locascio. 2004. Blossomend rot: A calcium deficiency. J. Plant Nutr. 27:123-139.

USDA. 2005. United States standards for grades of sweet bell pepper.

Wada, T., H. Ikeda, K. Matsushita, A. Kambara, H. Hirai, and K. Abe. 2006. Effects of shading in summer on yield and quality of tomatoes grown on a single-truss system. J. Jpn. Soc. Hort. Sci. 75:51-58.

White, P.J. and M.R. Broadley. 2005. Biofortifying crops with essential mineral elements. Trends Plant Sci. 10:586-593.

Zhang, Z.B. 2006. Shading net applications in protected vegetable production in China. Acta Hort. 719:479-482. 